UDC 342.9:347.9

DOI https://doi.org/10.32838/2707-0581/2020.2-2/19

Reshota $\boldsymbol{V} . \mathrm{V}$.

Ivan Franko National University of Lviv

\title{
FORMATION OF THE ADMINISTRATIVE JUSTICE IN EUROPE
}

The aim of the research is to investigate the establishment and development of the institute of administrative justice in the second half of the eighteenth - early twentieth century. The problems of origination and formation of administrative justice were analyzed through the prism of their historical development in the countries of Western Europe in the second half of the XVIII beginning of the XX centuries. It reflects the influence of the French Revolution and the establishment and development of the institute of administrative justice in Europe. The chronological sequence of the formation of administrative justice in European countries has been found. The influence of the ideas and theories of European researchers on the development of administrative justice is reflected in the article. Thus, administrative justice in Europe has passed through a long period of its formation and development. Some elements of its creation might be observed in ancient Greece and Rome, but in modern sense, the administrative justice emerged because of the distrust of the population to the king and the royal courts in France after the French Revolution. This facilitated the creation of new bodies within the public administration to resolve disputes between citizens and public authorities. The French model of administrative justice led to the emergence of this institution in other European countries. At the same time, the system of administrative justice was formed in German lands, where administrative courts were established within the judicial system of the state. This model has given rise to the formation of modern administrative justice in Ukraine.

Key words: administrative justice, public administration, theory of administrative justice, justice, Europe.

Introduction. For the realization of their rights and interests, any person intervenes with state bodies. Although they are not always interested to defend the violated rights and freedoms of human and citizen. For that purpose, the institute of administrative justice is created as a specific system of human rights protection in sphere of public administration. There are different administrative justice systems, which passed through special and sometimes difficult stages of their institutionalization under the influence of certain historical processes, traditions, customs and peculiarities of legal system etc. However, the development of administrative justice in all countries leads to an improvement of its institutional and functional characteristics. The historical method of administrative justice research will help to identify the regularities of its development and formation in different countries of the world.

The purpose of the research is to investigate the origin and formation of the administrative justice in Europe during the XVIII - early XX century.

Theoretical departures. According to many researchers of administrative justice, it originated in France because of the French bourgeois revolution of 1789-1794 [1, p. 260, 261; 3, p. 361, 362; 15, p. 11; 18, p. 10]. However, some pre-revolutionary Russian scientists such as M. Kovalevskyi and F. Taranovskyi argued that the institution of administrative justice had its own prehistory. They stated that its origin might be traced back as early as ancient and medieval Europe [21].

The problem of protection of rights of free men from the oppression of public officials arose in ancient Greece and ancient Rome. Although these questions had no theoretical grounds in that times, but human's freedom was recognized as the biggest value and was protected from arbitrariness of rulers. In Athens, law protected the right to liberty and security of free person.

In the republican period in Rome, a guarantee was provided for every free citizen, offended by the consul, praetor or other official, to apply to the people's assembly (later the people's tribunes) with a request to protect him or her from the arbitrariness of officials $[13$, p. 3]. In this way, a mechanism for the protection of citizens' rights was created. It resolved a problem of relations between a citizen and public authorities.

The elements of administrative justice may be traced in medieval Europe. For instance, in the midthirteenth century an institution of justices of the peace was formed in England. Large landowners were obliged to fulfill obligations of justices of the peace, 
which combined the functions of management and administrative justice. Justices of the peace were empowered to resolve disputes of residents with tax, police and other authorities. Although this position initially was rather administrative, than judicial, but since the XIV century its administrative functions were shortened, while its criminal jurisdiction expanded. The majority of their administrative functions were delegated to local self-governments $[20$, p. 35,36$]$.

In the age of feudalism in France, Germany and Italy, the courts played an important role in the handling of complaints by individuals against public authorities. In medieval France, the highest judicial and administrative institutions were the parliaments, which were operating in all the provinces of the country. A well-known Russian researcher wrote about them the following: "The general judicial competence of parliaments allowed them, at the same time, to perform functions of administrative courts, deciding disputable questions of public law" [21].

This order of protection of public rights was also adopted by other absolute monarchies of Western Europe. This mechanism for protecting of human rights existed until the Great French Bourgeois Revolution of 1789-1794, which created a completely new model of administrative justice. Majority of scholars consider it as a "classical" model of administrative justice $[15$, p. $11 ; 17$, p. $36 ; 22$, p. 116]. The creation by Napoleon of the State Council, which later became the highest administrative justice body of France, and the prefectural councils as administrative justice of first instance, may be attributed to the most important transformation that characterized that era. This innovation reflected the doctrine of separation of powers according to which administrative disputes neither could not be solved by the administration itself, nor transferred to the courts of general jurisdiction, as they could be subordinated to the bodies of executive power in this way [17].

French administrative law researcher G. Breban noted that "current administrative justice was created as a result of distrust of the revolutionaries of the judiciary and necessity to provide jurisdictional control over the administration by any mean" $[3, p$. 362]. The judiciary had represented the interests of the monarchy for a long time in France, and therefore there was a need to establish an independent body to handle administrative disputes. Courts lost their authority and confidence over the population, so it was necessary to deliver these functions to the active administration itself. However, this cannot be determined as the main or the sole cause institution of the modern administrative justice. Hence, the creation of administrative justice in different countries has become possible due to certain socio-economic and legal conditions, as well as due to thorough theoretical development of effective mechanisms of judicial protection of subjective rights and legitimate interests of persons, violated by acts, actions or inactions of executive authorities and their officials [14, p. 49].

The prerequisite for the emergence of administrative courts, which are the bodies of administrative justice in the countries of the continental legal system, was the strengthening of royal power and the tendency to divide legislative, executive and judicial functions between the authorities of a state. The French bourgeois revolution played the role of catalyst in this process together with socio-economic and legal transformations. In particular, the replacement of local self-government bodies by state bodies, the weakening of the influence of the classes, especially of the nobility, on public life, was accompanied by the creation of special mechanisms for the protection of individual's rights against the arbitrariness of bureaucrats [12, p. 32, 71-79, 95-105]. Regarding the legal prerequisites of administrative justice creation, it should be noted that in the end of the eighteenth century, there was a delineation of private and public law in France, Germany and other continental law countries. Except that, the administrative law was separated into a separate branch industry, the theory of the rule of law was being developed, and questions of distribution of state power were investigated.

M. Kuplevaskyi, the Ukrainian lawyer, public and political figure, noted in his book "Administrative Justice in the Western Europe. The Administrative Justice in France" (1879) that the need for the establishment of administrative justice bodies also lies in the fact that often between individuals or legal entities there can be disputes with the "administration" which have nothing to do with the criminal process [11, p. 148]. The reasons for these disputes are the different understanding by the parties of a conflict of their rights, diverse assessment of the facts, and different interpretation of the law. Therefore, in such cases, it is necessary to have a separate body to settle the dispute and set up the boundaries for the administration or the private person or to abolish the illegal administrative acts of the administration and restore the violated rights of individuals or legal entities.

Apart from the aforementioned reasons, the idea of the separation of powers had certainly a huge impact on the development of administrative justice. Thus, 
formation of administrative justice in France was considered because of the separation of administrative and judicial authorities and non-interference of the general courts in activity of the government. Although, today the main task of administrative justice is to protect the rights and freedoms of citizens in public administration and local self-government.

Thus, the basis factors for administrative justice emergence and development were of socio-historical and legal nature. It has evolved historically, throughout the period of human development. The establishment of administrative courts (tribunals) in France has become an important stage in the development of the institution of administrative justice, spreading on other continental law countries.

\section{Creation of administrative justice in France}

The administrative courts were established first in France not by accident. The administrative justice here had been investigated as a scientific problem; many scientific researches on this topic appeared there as well. In the early XIX century in France a corresponding scientific base was formed. In 1817, a department of administrative law was created in the Paris University based on administrative justice legislation [6, p. 214]. It should be noted that in textbooks on administrative law a particular attention was payed administrative justice, which was part of the course on administrative law at universities.

Scientific studies of administrative justice became the basis for the creation of its theories, which were of great importance for the formation of this institution in many states. The issue of administrative justice began to occupy an important place in the scientific literature of the mid-19th century. According to Russian jurist M. Korkunov, "the doctrine of administrative justice has gained a place in general courses of state and administrative law. No handbook could omit a separate section on administrative justice $<\ldots>$ The former reactionary scare has even become popular, based on scientific theory" [10, p. 146].

Conclusions. The issue of administrative justice remains relevant today, even in those countries where this institution has been established [8]. For example, some French scholars M. Oriu, J. Vedel, M. Lesage, G. Breban and other continued to study the institute of administrative justice in the XX century. In their works, they emphasized the particular role of administrative justice, which it played in the public life of France, in particular in the control over the French administration and the protection of the rights and freedoms of French citizens.

While the French and German theories of administrative justice had a great influence on the emergence and establishment of this institution in many continental European countries, the situation was different in the Anglo-Saxon model countries [2, p. 117]. Here, the theory of administrative justice was not developed, because by the midtwentieth century the concept of general equality before the general court was dominant. It enabled the right to challenge acts of public administration to these courts. Accordingly, there was no need to set up separate administrative courts. Thus, at the beginning of the XX century, the absence of administrative courts in England was explained by the broad competence of the general courts, which asserted the right to control all important matters of government and matters relating to citizens' rights, as well as the broad development of local selfgovernment and the constant scrutiny of the public and parliament administration [4, p. 439].

As for issue of formation of the institute of administrative justice in Russian Empire, it should be stated imperial ideas about the state dominated there. Only at the turn of the nineteenth and twentieth centuries, during theperiodof "Europeanmodernization of the country", the administrative justice became the subject for Russian and Ukrainian researchers. The issue of the emergence and development of administrative justice ideas on the Ukrainian lands has been already the subject of our research [16].

Therefore, the institute of administrative justice has undergone a long and complicated process of its formation and development. The emergence of administrative justice in each country was due to the peculiarities of historical development, the evolution of legal ideas, values, customs and traditions of the legal system. The decisive influence on its emergence had theoretical studies of administrative justice and theories developed by many European researchers, which formed the basis for the world's systems of administrative justice. Today, these ideas are a fundamental factor in the implementation of the institutions of democracy, the protection of the rights and freedoms of citizens, the formation of the rule of law and civil society.

\section{References:}

1. Бандурка О., Тищенко М. Адміністративний процес : підручник для вищих навчальних закладів. Київ : Літера Лтд., 2002. 288 с. 
2. Бояринцева М. Розгляд та вирішення адміністративних спорів в зарубіжних країнах. Актуальні проблеми вітчизняної юриспрудениії. 2019. № 4. С. 116-120.

3. Брэбан Г. Французское административное право / под ред. и со вступ. ст. С. Боботова. Пер. с фр. Москва : Прогресс, 1988. 488 с.

4. Водовозовъ В. Административная юстиція. Энциклопедическій словарь т-ва "Бр. А. и И. Гранать u $K^{\circ}$ ” : в 58 т. / под ред. В. Жельзнова и др. Санкт-Петербургъ : Бр. А. и И. Гранатъ и К, 1890-1907. Т. 1. 1890. С. $432-434$.

5. Гнейст Р. Правовое государство и административные суды Германии / пер. Ф. Фустова ; подъ ред. М. Свъшникова. Санкт-Петербургъ : Типографія В. Безобразова и Комп., 1896. 371 с.

6. Заверуха О. Адміністративна юстиція: поняття, правовий зміст та характерні ознаки. Вісник Львівського національного університету. 2003. № 38. С. 212-218.

7. Зіллер Ж. Політико-адміністративні системи країн $Є С$ : порівняльний аналіз. Пер. з фр. В. Ховхуна. Київ : Основи, 1996. 420 с.

8. Золотухіна Л. Адміністративна юстиція як складова адміністративно-правового механізму публічного інтересу. Актуальні проблеми вітчизняної юриспрудениії. 2019. № 4. С. 138-143.

9. Коркунов Н. Русское государственное право : в 2-х т. Санкт-Петербургъ : Типографія М.М. Стасюлевича, 1913. Т. 2 : Часть особенная. 1913. 739 с.

10. Коркунов Н. Сборникъ статей. 1877-1897. Санкт-Петербургъ : Изд. юрид. книжного магазина Н.К. Мартынова, 1898. 739 с.

11. Куплеваський М. Административная юстиция во Франции. Антологія української юридичної думки : в 6-ти т. / за ред. Ю. Шемчушенка (голова) та ін. Київ : Юридична книга, 2003. Т. 5 : Поліцейське та адміністративне право / упоряд. Ю. Римаренко, В. Авер'янов, І. Усенко. С. 143-174.

12. Лемайеръ К. Административная юстиція. Понятіе охраны субъективныхъ прав въ связи съ развитіемъ воззръній на государство. Пер. с нем. А. Нольде. Санкт-Петербургъ : Сенатская Типография, 1905. $206 \mathrm{c}$.

13. Лесницкая Л., Хаманева Н. Гражданин обратился с жалобой. Москва : Знание, 1990. 64 с.

14. Пахолок Л. Адміністративна юстиція в зарубіжних країнах: виникнення і сучасний стан. Вісник Верховного Суду України. 2001. № 5. С. 49-54.

15. Педько Ю. Становлення адміністративної юстиції в Україні : монографія. Київ : Ін-т держави і права ім. В.М. Корецького НАН України, 2003. 208 с.

16. Решота В. Передумови формування адміністративного судочинства в Україні. Юридичний науковий електронний журнал. 2015. № 3. C. 124-127. URL: http://lsej.org.ua/3_2015/36.pdf (дата звернення: 12.03.2020).

17. Сажина В. Административная юстиция: к теории и истории вопроса. Советское государство и право. 1989. № 9. С. 36-44.

18. Сажина В. Административная юстиция Великобритании : автореф. дис. ... канд. юрид. наук: 12.00.02. Москва, 1984. 23 с.

19. Токвіль А. Давній порядок і революція. Пер. 3 франц. Г. Філіпчук. Київ : Юніверс, 2000. 224 с.

20. Уолкер Р. Английская судебная система. Москва : Юридическая литература, 1980. 632 с.

21. Усанов В. Проблемы формирования административной юстиции в России. Право и жизнь. URL: http://www.pravogizn.h1.ru (дата звернення: 20.01.2020).

22. Хаманева Н. Защита прав граждан в сфере исполнительной власти. Москва : Инситут государства и права РАН, 1997. $216 \mathrm{c.}$

23. Чечот Д. Административная юстиция : теоретические проблемы. Ленинград : Изд-во Ленинградского ун-тета, 1973. $133 \mathrm{c}$.

24. Lindseth P. "Always Embedded" Administration: The Historical Evolution of Administrative Justice as an Aspect of Modern Governance. University of Connecticut School of Law Working Paper Series. 2004. № 19. P. 31.

\section{Решота В.В. ФОРМУВАННЯ АДМІНІСТРАТИВНОЇ ЮСТИЦІї В ЄВРОПІ}

Досліджено становлення та розвиток інституту адміністративної юстииії у другій половині XVIII - на початку XX століття. Проблеми виникнення та формування адміністративної справедливості були проаналізовані крізь призму їх історичного розвитку у країнах Західної Свропи другої половини XVIII - початку XX століття. Він відображає вплив Франиузької револючії та створення та розвиток інституту адміністративної юстиції в Європі. Виявлено хронологічну послідовність формування адміністративної юстииї в європейських краӥнах. Відображено вплив ідей $і$ теорій європейських дослідників на розвиток адміністративної справедливості. Отже, адміністративне правосуддя в Свропі пройшло тривалий період свого становлення та розвитку. 
Деякі елементи його створення можна спостерігати у Стародавній Греиії та Римі, але в сучасному розумінні адміністративна справедливість виникла через недовіру населення до короля та королівських дворів у Франиії після Франиузької революиії. Це сприяло створенню нових органів у межах публічної адміністраиії для вирімення суперечок між громадянами й органами державної влади. Франиузька модель адміністративного судочинства привела до появи иього інституту в інших європейських країнах. Водночас на німецьких землях формувалася система адміністративного судочинства, де в рамках судової системи держави були створені адміністративні суди. Ця модель породила формування сучасного адміністративного судочинства в Україні.

Ключові слова: адміністративне правосуддя, державне управління, теорія адміністративного судочинства, справедливість, Європа. 